\title{
The Effect of Gases on Nuclear Division.
}

\author{
BY
}

\author{
FRANK M. ANDREWS, \\ Assistant Professor of Botany in Indiana University, Bloomington, Ind., U.S.A.
}

With a Figure in the Text.

$\mathrm{E}^{\mathrm{n}}$ VER since the appearance of Demoor's paper ${ }^{1}$ on the physiology of the cell, considerable doubt has been expressed as to the exactness of many of his experiments and conclusions ${ }^{2}$. It was in the hope of removing this doubt that $I$ began an investigation at the suggestion of Prof. Pfeffer, during my study in Leipzig in 1902, to ascertain the correctness of Demoor's work. My experiments, to be described presently, do not include the whole of the work mentioned in the paper of Demoor cited below, but deal only with Chapter IV (pp. 30-54). This chapter contains the results of his experiments on the staminal hairs of Tradescantia virginica, especially under the influence of different gases, with reference to protoplasmic and nuclear activity. It is, however, his statement that the nucleus can be divided independently of the protoplasm that is most important and has caused most controversy, and it is this question that I have tried especially to decide by my experiments.

\section{Methods.}

Momordica Elaterium was used only for a few experiments on the movements of protoplasm. The best as well as the most certain living object, however, in which nuclear and cell-division can be directly followed is Tradescantia virginica ${ }^{3}$, and accordingly this plant was chosen for my investigations. The younger staminal hairs, and those containing cells whose nuclei had not yet divided, were selected and put in a 3 per cent. solution of cane sugar to see the division take place. This solution is not concentrated enough to produce plasmolyzation, nor does it apparently interfere in any way with the vital activities of the cell-at

' Contribution à l'étude de la physiologie de la cellule. Archives de Biologie, tome xiii, I894.

2 Pfeffer, Pflanzenphysiologie, 2. Aufl., Bd. ii, p. 46. Samassa, Ueber d. Einwirkung von Gasen auf d. Plasmaströmung, Bot. Zeitung, 1898.

${ }^{8}$ Strasburger, Botanisches Practicum, 4. Aufl., 1902, p. $5^{89}$.

[Annals of Botany, Vol. XIX. No. LXXVI. October, 1905.] 
least within the limits which concern us here ${ }^{1}$. A stronger solution of cane sugar ( 5 per cent.) may, as Hörmann ${ }^{2}$ has shown, cause a retardation of protoplasmic movement in a cell of Nitella. It was also very noticeable that the movement of the protoplasm in the younger cells of the staminal hairs was more readily and quickly affected by the influence of various gases than in the older cells whose cell-walls were, as one would naturally suppose, less permeable. This disregard of the age and condition under which the plant-cells live, and the attempt to apply the same tests to different plants and obtain similar results, has led to numerous errors on the part of many investigators.

Great care has been necessary in these experiments. The perfection of the apparatus, and the nature of the plant-material it was necessary to use, would make it at once evident to any one at all conversant with such a subject as this how very difficult it often is to arrive at a definite and certain result. In order to be sure that my results were correct, I have repeated each experiment several times.

It is not surprising then that Demoor made mistakes in some of his experiments and conclusions. While his general methods were good, he did not take sufficient precaution to obtain gases that were absolutely pure. The same lack of care in obtaining absolutely pure gases caused Lopriore ${ }^{3}$ to make some mistakes in his experiments and to arrive at entirely incorrect conclusions.

The only way to ascertain that no oxygen remains about the specimen under investigation is by means of the Bacterium-method of Engelmann. Pure cultures were obtained according to the method given by Detmer ${ }^{4}$, and these were used in all my experiments with hydrogen. It is certain, as I shall show later on in this paper, that even a very small quantity of oxygen is sufficient to allow the nucleus to commence and continue its division normally. Since, however, by the excessively delicate reaction shown by the Bacterium-method the billionth part of a milligram of oxygen can be detected ${ }^{5}$, I was thus able to ascertain the slightest trace left in the apparatus or if any should be evolved by the plant-cells under observation.

The natural evolution of oxygen by chlorophyll-bearing cells introduced another difficulty, but nevertheless made it absolutely necessary to avoid using any cells containing even a trace of chlorophyll.

Since absolute purity of the gases employed is essential for obtaining correct results, the utmost precaution was taken to construct apparatus and to use only those chemicals that would attain that end.

1 Ewart, on the Physics and Physiology of Protoplasmic Streaming in Plants, 1902, p. 59.

2 Studien über die Protoplasmaströmung bei den Characeen. Jena, 1898, pp. $5^{1-5}$.

s Jahrb. f. wiss. Bot., I 895 , Bd. 38, p. 53 I.

4 Pflanzenphysiologie, 2. Auf., 1895, p. $3^{2}$.

${ }_{5}^{5}$ Pfeffer, Pflanzenphysiologie, 1897,2 . Auf., Bd. I, p. $29^{2}$ and literature cited there. 
Figure 16 will give an idea of the apparatus used to obtain pure hydrogen. It consists of a gas generator $A$, containing zinc and sulphuric acid covered with paraffin ${ }^{1}$, which connects with a $\mathrm{U}$-tube $B$, filled with pumice stone and saturated with caustic potash for removing the hydrochloric acid, sulphuric dioxide or hydrogen sulphide, some one or more of which may be present in hydrogen prepared by the action of sulphuric acid on zinc. The $\mathrm{U}$-tube $B$ is connected with $C$ containing silver nitrate for absorbing the arsenic according to the formula :-

$$
6 \mathrm{AgNO}_{3}+\mathrm{AsH}_{3}+3 \mathrm{H}_{2} \mathrm{O}=6 \mathrm{Ag}+\mathrm{H}_{3} \mathrm{AsO}_{3}+6 \mathrm{HNO}_{3} \text {. }
$$

The $U$-tube $C$ is joined to $D$ containing pyrogallol for removing the oxygen. $D$ communicates with $E$ containing potassium permanganate, and $E$ with the bottle $F$ containing water for washing the hydrogen and saturating it with moisture. This latter precaution is absolutely essential, for if dry gas were allowed to enter the gas chamber $G$ on the microscope $P$, the shallow drop of water containing the specimen for observation would be evaporated before the termination of the experiment. In order to ascertain the rate of flow of the gas, as well as to prevent any back flow of air into $G$, a bottle $K$ is attached containing water. The glass tubes connecting the $U$-tubes and bottles are made secure at their points of union by rubber stoppers covered with a thick layer of sealing wax as at $L$. The glass tubes $M, M^{\prime}$ are long enough to allow sufficient movement of $G$. They are fastened to the metal tubes of the gas chamber $G$ by rubber tubing covered with sealing wax. Such connexions as are here mentioned will not allow any gas to diffuse, as I have found by long-continued experiments. No leakage whatever could be detected, even when the gas in the apparatus was subjected to a pressure of half an atmosphere under water.

Another excellent method is to generate hydrogen by electrolysis and collect this in a vessel for use.

\section{The EFFect of Hydrogen.}

\section{The action of Hydrogen on the streaming of Protoplasm.}

In each case after the staminal hair was placed in the 3 per cent. solution of cane sugar a few of the aerobic Bacteria, above referred to, were transferred to the drop by means of a sterilized platinum needle. These Bacteria move when oxygen is present. They also instantly cease moving when oxygen entirely disappears, and are therefore a very delicate test to show that no oxygen was around the cells with which I was experimenting. The use of the various chemicals mentioned has, by the

1 If, as sometimes happens, the sulphuric acid does not attack the zinc readily, so as to cause a rapid evolution of hydrogen, this may be brought about by the addition of a small quantity of platinum tetrachloride or copper sulphate to the sulphuric acid. 
524 Andrews.-The Effect of Gases on Nuclear Division.

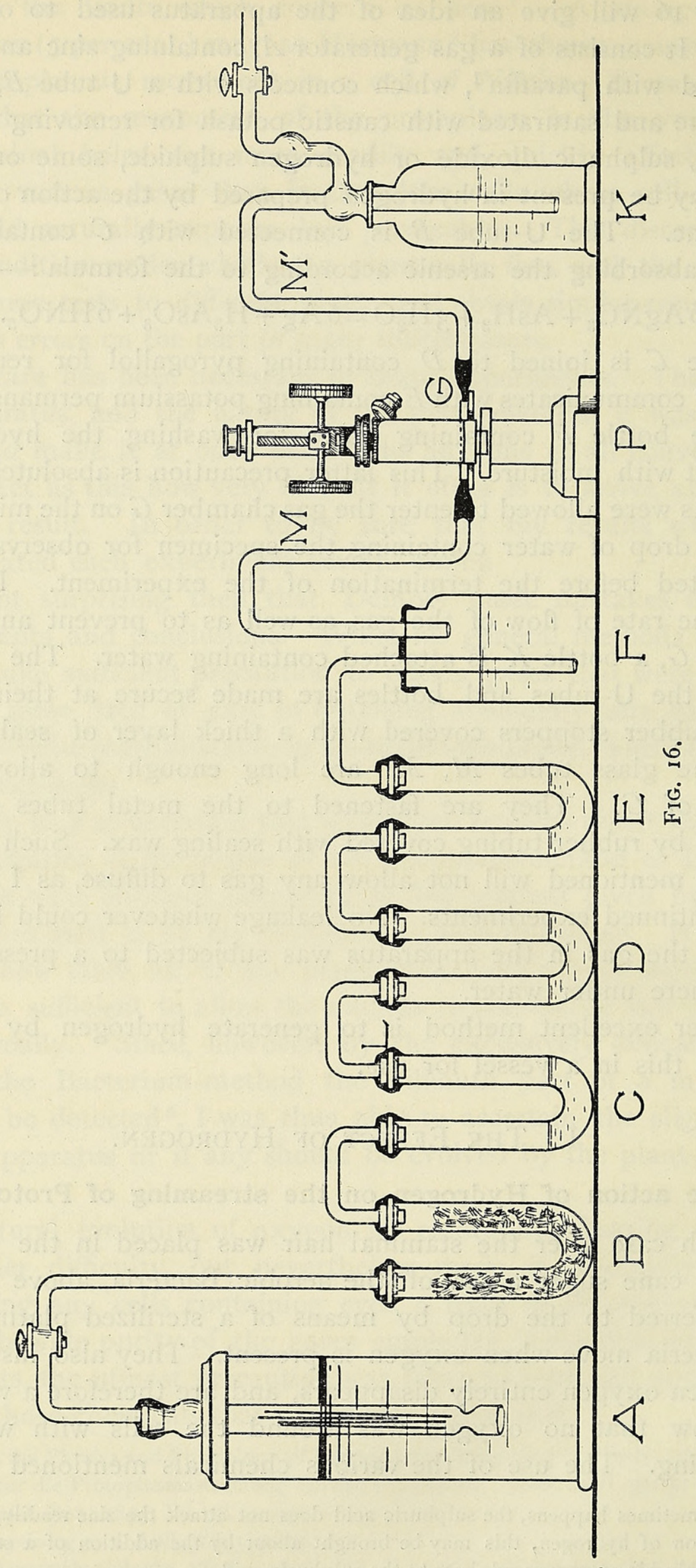


time hydrogen reaches the cell enclosing the material for investigation, removed all other gases and impurities, leaving pure hydrogen.

In the first experiment a cell of Tradescantia virginica was placed in pure hydrogen and in ten minutes the movement of the protoplasm ceased. To ascertain just when the protoplasm stops moving requires great care and accurate observation, since a very slight movement is easily overlooked. One hour and four minutes afterwards oxygen was introduced and the movement began again in five minutes. This experiment is verified by the action of hydrogen on the cells of Momordica Elaterium, for when the cells of this plant were subjected to pure hydrogen the movement of the protoplasm ceased in ten minutes and began again in five minutes as before. When, however, the cells of Momordica Elaterium were left in pure hydrogen for six hours they were not killed, but the time of recovery and recommencement of movement was thirty minutes. That a longer time should be required when left in pure hydrogen is not surprising, but shows that if all other conditions were perfect in every way a very long time would be required to kill these plant-cells in pure hydrogen.

The three preceding experiments on non-chlorophyll cells of Tradescantia virginica and Momordica Elaterium were carried on in light; but others exactly the same, except that they were kept in darkness, were performed with no appreciable difference in the results.

\section{Influence of Hydrogen on Nuclear Divisions.}

When a nucleus in the resting stage is left in pure hydrogen it cannot begin division. This was verified by bringing resting nuclei of Tradescantia virginica into pure hydrogen for four and one-half hours, at the end of which time they still remained in the resting stage and not the slightest advance toward division had taken place. At the end of this time (four and one-half hours), when air was admitted, the nuclear division commenced and was completed.

When a nucleus was near the close of the prophase stage and was brought under the influence of pure hydrogen, indirect division was completed and the formation of the daughter-nuclei occurred, but no cell-wall was ever formed.

Such nuclei finished dividing in two hours. The nuclei which I used as controls showed that this is somewhat longer correspondingly than is required by nuclei of Tradescantia virginica under normal conditions to divide. It further shows that the cessation of protoplasmic activity and passage of the hydrogen through the protoplasm to the nucleus is comparatively slow for such a gas, and thus nuclear division is able to advance considerably before being checked by its influence. In all these ex- 
periments the motionless aerobic Bacteria showed the total absence of oxygen.

When oxygen was admitted, after each of these experiments, a cellwall was produced in fifteen minutes. These and many other experiments performed in this way show that it is impossible for the nucleus to divide independently of the protoplasm. That the nucleus could not begin division in pure hydrogen, whereas in the control experiments it could, shows this to be true. That nuclear division advanced in pure hydrogen without the formation of the cell-wall is to be explained simply and only on the ground that the hydrogen could not penetrate quickly enough to prevent a certain advance in nuclear division or interfere with the vital processes of the nucleus, as it had with those of the more exposed cytoplasm.

\section{The Effect of Carbon Dioxide.}

In the second set of experiments, where carbon dioxide was used, the apparatus shown in Fig. 16 was not employed. This gas was purified and freed from all traces of oxygen and then washed with water and subsequently tested to see that no oxygen remained. Its interference both with protoplasmic streaming and nuclear division was more marked than that of hydrogen.

\section{Effects of Carbon Dioxide on the Movements of Protoplasm.}

In the cells of the hairs of Momordica Elaterium the streaming of the protoplasm ceased in six minutes after admitting carbon dioxide. The specimens were left in a constantly flowing stream of carbon dioxide for three hours, during which time no movement of the protoplasm was evident. When oxygen was allowed to enter, the movement began again in ten minutes. In Tradescantia virginica the same effect and time-relation was observed.

\section{Effects of Carbon Dioxide on Nuclear Division.}

Nuclei of Tradescantia virginica in the resting stage were left in pure carbon dioxide for two and one-half hours, and did not commence division. They seemed at the expiration of this time to be slightly disorganiżed. Recovery of the nucleus was possible if the disorganization had not proceeded too far. Whenever nuclear division did occur after this disorganization it was always by karyokinesis.

A cell of Tradescantia virginica, whose nucleus was near the close of the prophase stage, was left in carbon dioxide for three hours, but no further division of the nucleus occurred. After thirty minutes, oxygen was again admitted, when the protoplasm first began to move, then the nucleus to divide, completing its division and forming a cell-wall in one hour and forty minutes. This, as in the similar case of hydrogen, was somewhat 
longer for the nucleus to finish division than was required by the control specimens.

In a third series of experiments with carbon dioxide, a cell of Tradescantia was left in the gas for fourteen hours. At the expiration of this time, as would be expected, the cell was dead. This disproves the statement of Lopriore ${ }^{1}$, who states that carbon dioxide may act for days (together) before causing a permanent cessation of protoplasmic movement. His error was evidently due to the use of impure carbon dioxide.

\section{EFFects of a VacuUm on Nuclear Division.}

As stated, a very small quantity of oxygen is sufficient to allow nuclear division. By using a vacuum pump a pressure of $3 \mathrm{~mm}$. of mercury was reached and maintained. Even at this slight pressure, resting nuclei, as well as those farther advanced, completed division and formed a cellwall. The movement of the protoplasm does not cease even at this low pressure, showing the incorrectness of Demoor's statement, that it stops at a pressure of 6 to $12 \mathrm{~cm}$. of mercury. Whenever, for whatever reason, the activity of the protoplasm is made impossible, that of the nucleus is also suppressed.

\section{Effects of Ethyl Ether.}

In the experiments with ethyl ether and chloroform the specimens were not put directly in the solution mentioned, but the vapour from these solutions was drawn over the cells, while in the sugar solution, by means of an aspirator.

In the vapour of a $\mathrm{I}$ per cent. or stronger solution of ethyl ether resting nuclei of Tradescantia virginica cannot begin division. Those nuclei, however, which had begun division, completed it or advanced towards completion according to the concentration of the solution, as the following experiments will show.

In the vapour of a I per cent. solution of ethyl ether the nucleus, when in the prophase stage, finished division about ten minutes sooner than the control specimen. A series of experiments were sufficient to establish the fact that, as in the case of the movement of the protoplasm, a slight acceleration in rapidity of nuclear division was produced with a I per cent. solution of ethyl ether.

The formation of the cell-wall also commenced even before the chromosomes began to separate and to move to their respective poles. A somewhat similar cell-division has been observed by Gerassimoff ${ }^{2}$ in Spirogyra under certain conditions. The resulting nuclei were normal in appearance.

In a 3,4 , and 5 per cent. solution of ethyl ether the nuclei, when near

${ }^{1}$ Jahrb. f. wiss. Bot., 1895, Bd. 28, p. 57 I. ${ }^{2}$ Pfeffer, Pflanzenphysiologie, 2. Auf., Bd. II, p. 46. $\mathrm{O}$ o 
the end of the prophase stage, finished division and formed a cell-wall as soon as the chromosomes had separated. The movement of the protoplasm was slightly accelerated for a short time, as was also the division of the nucleus, as shown by the control specimen. The daughter-nuclei, which at first were not regular in form, became so after a time.

In a 6 per cent. solution of ethyl ether the nuclei finished cell-division and formed a cell-wall. An hour later the protoplasmic movement was still noticeable, but the daughter-nuclei appeared vacuolated and did not become round as usual. At the expiration of twelve hours the cells which had been left in this solution of ethyl ether were dead.

In a 7 per cent. solution of ethyl ether the nuclei in the prophase stage made no advance towards completing division, and the protoplasm, which showed at first a feeble movement in the older cells, stopped in fiftyfive minutes. When not left under the influence of a 7 per cent. solution too long, the nuclei began to divide again, but always by karyokinesis. In all the experiments with ethyl ether, as with the other reagents, it was seen that if the activity of the protoplasm was accelerated or retarded, or if the protoplasm was killed, the nucleus was in a short time likewise affected. My experiments further show that the nuclei of the staminal hairs of Tradescantia virginica cannot, as stated by $A$. Nathansohn ${ }^{1}$, be made to divide amitotically through the influence of ethyl ether. It may, as just stated, only hasten slightly or prevent division according to the strength of the solution used. When sprays of Tradescantia virginica, with cells of the right age for cell-division, are, as Nathansohn states, placed under a bell-jar in water along with a dish containing a $2-2.5$ per cent. solution of ethyl ether, the nuclei do not divide amitotically. Karyokinesis is only arrested, and begins again in a short time after admitting fresh air.

\section{EFFECT of Chloroform.}

When the cells of Tradescantia virginica were placed in a drop of a 3 per cent. solution of cane sugar and the air from a solution of chloroform-water diluted one-half with water was drawn over the cells, the nuclei in the prophase stage completed division and a cell-wall was formed. The movement of the protoplasm, which finally ceased, recommenced when brought into fresh water after three hours. Resting nuclei in a solution of chloroform-water diluted one-half with water did not divide. The air drawn from pure chloroform, as expected, killed all cells.

\section{EFFECT OF COLD.}

It is impossible for a nucleus at $-3^{\circ}$ or $-4^{\circ} \mathrm{C}$. to divide under any circumstances, as stated by Demoor. Even at $0^{\circ} \mathrm{C}$. a nucleus cannot

\footnotetext{
${ }^{1}$ Jahrb. f. wiss. Bot., 1900, Bd. 35, p. 70.
} 
divide. When, however, nuclei were subjected to a temperature of $\mathrm{I} \cdot 5^{\circ} \mathrm{C}$., they finished dividing and formed a cell-wall when in the prophase stage. Resting nuclei do not divide at less than $7^{\circ} \mathrm{C}$., and then very slowly. When the nucleus is kept at $0^{\circ} \mathrm{C}$. for a time and then gradually brought back to warmer air, as for example $20^{\circ} \mathrm{C}$., the division will be completed and a cellwall formed after three hours. The movement of the protoplasm was not visible at a temperature at which the nucleus could not divide.

\section{EFFECT OF HEAT.}

When nuclei in the prophase stage were subjected to a temperature of $34^{\circ} \mathrm{C}$. they finished dividing, but no cell-wall was formed. The time for division was increased by one half as shown by the controls. When the temperature was lowered to between $20^{\circ} \mathrm{C}$. and $30^{\circ} \mathrm{C}$. the cell-wall was formed. The nuclei always appeared normal, and no tendency to direct division, with either heat, cold, or any other agency, was observed.

\section{ViII. Effects of Ammonium Carbonate.}

Placed directly in a $\frac{1}{4}$ and $\frac{1}{2}$ per cent. solution of ammonium carbonate, the nucleus of Tradescantia virginica, when in the prophase stage, finished dividing and formed a cell-wall in fifty minutes. The daughter-nuclei were irregular in form.

In a I per cent. solution of ammonium carbonate the nucleus which had begun to divide stopped almost immediately. When, after one minute, fresh water was again supplied, it began again and completed division. If left longer than one minute in a I per cent. solution the protoplasm and nucleus were killed.

\section{SUMMARY.}

The foregoing experiments warrant the following conclusions concerning nuclear division in Tradescantia virginica and the movements of the protoplasm in this plant and Momordica Elaterium:-

1. The protoplasm of these plants cannot move in a pure atmosphere of hydrogen or carbon dioxide.

2. Nuclei in the resting stage cannot divide in pure hydrogen or carbon dioxide. When, however, a nucleus is near the close of the prophase stage, it may complete division but never forms a cell-wall. The further division of the nucleus is only continued till the hydrogen or carbon dioxide kills or disables the protoplasm or penetrates to the nucleus, for when the nucleus is just beginning division it cannot complete division in pure hydrogen or carbon dioxide.

3. A very slight pressure $(3 \mathrm{~mm}$.) of oxygen is sufficient for the nucleus to divide. 


\section{Andrews. - The Effect of Gases on Nuclear Division.}

4. Resting nuclei in a I per cent. or stronger solution of ethyl ether cannot begin division. In $I, 2,3,4,5$, and 6 per cent. solutions of ethyl ether, nuclei in the prophase stage finished division and formed a cell-wall, both processes taking place in somewhat less time than the controls. In a ? per cent. solution of ethyl ether no advance towards completing division was made.

5. In a $\frac{1}{2}$ per cent. solution of chloroform water, nuclei in the prophase stage divided and a cell-wall was formed. Resting nuclei could not divide.

6. Nuclei in the prophase stage can divide at $\mathrm{I} \cdot 5^{\circ} \mathrm{C}$. Resting nuclei cannot divide below $7^{\circ} \mathrm{C}$.

7. Nuclei in the prophase stage can finish dividing, but form no cellwall at $34^{\circ} \mathrm{C}$.

8. Nuclei in the prophase stage in a $\frac{1}{4}$ or $\frac{1}{2}$ per cent. solution of ammonium carbonate can divide and form a cell-wall. In a I per cent. solution of ammonium carbonate nuclei in any stage cannot divide.

9. Whenever nuclear division occurred in these experiments it was always by karyokinesis.

IO. These experiments show that, contrary to the opinion of Demoor, the nucleus cannot divide independently of the protoplasm, and that if the protoplasm is killed or temporarily disabled the nucleus is also soon likewise affected. The only reason that the nucleus continues to divide is that a little time is naturally necessary for the reagent to affect the protoplasm or to reach the nucleus. Even when the activity of the protoplasm just ceases, nuclear activity ceases also. It is just as impossible for the nucleus to divide after the protoplasm has been killed or its activity annulled as it is for either the nucleus or protoplasm when separated to continue to live, no matter how perfect all other conditions may be.

In conclusion it is my pleasant duty to express my thanks to Prof. Pfeffer for his constant kindness and advice in these experiments. 


\section{$2 \mathrm{BHL}$ Biodiversity Heritage Library}

Andrews, Frank. 1905. "The effect of gases on nuclear division." Annals of botany 19, 521-530. https://doi.org/10.1093/oxfordjournals.aob.a089026.

View This Item Online: https://www.biodiversitylibrary.org/item/233541

DOI: https://doi.org/10.1093/oxfordjournals.aob.a089026

Permalink: https://www.biodiversitylibrary.org/partpdf/318814

\section{Holding Institution}

Smithsonian Libraries

\section{Sponsored by}

Biodiversity Heritage Library

\section{Copyright \& Reuse}

Copyright Status: Not in copyright. The BHL knows of no copyright restrictions on this item.

This document was created from content at the Biodiversity Heritage Library, the world's largest open access digital library for biodiversity literature and archives. Visit BHL at https://www.biodiversitylibrary.org. 